\title{
for(e)dialogue
}

Department of Media and Communication

Volume 2, Issue 1: Special Issue (Forced) Migration and Media

Assessing the freedom of expression of Syrian refugee media outletsMaria Assaf

(p. 50-66)

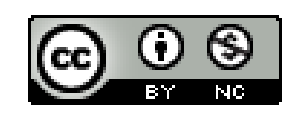

This work is licensed under a

Creative Commons Attribution- Non Commercial 4.0 International License

June 2018 


\section{Assessing the freedom of expression of Syrian refugee media outlets}

\section{Maria Assaf}

Abstract: Syrian post-uprising media outlets arose during the peaceful phase of the Syrian uprising in early 2011 (Salazar-Ferro, CPJ, 2014). Fewer than 30 of these outlets, funded by Western countries, survived and gradually moved to Turkey, escaping censorship and deteriorating security in Syria. In Turkey, they still face challenges such as security threats and an uncertain legal status. This article focuses on the challenges that threaten refugee reporters' freedom of expression. Its aim is also to bring an understanding of the techniques refugee journalists use to mitigate these challenges, which can inform other reporters in similar conditions. This research was carried out utilising a case-studies framework and speaking to seven editors in chief of post-uprising media outlets in Istanbul. It concludes that Syrian post-uprising media face severe restrictions to their freedom of expression, but survive through a mixture of collaboration, creativity and resourcefulness.

Keywords: refugees, freedom of expression, journalism, conflict, Syria, Turkey.

\section{Introduction}

By 2014, more than 70 Syrian journalists had fled censorship and a lack of safety in Syria (Salazar-Ferro, 2014) and many had moved to Turkey. This research explores the freedom of expression of refugee media outlets by drawing upon interviews with seven Syrian postuprising reporters based in Istanbul, Turkey, and three Syrian refugee media professionals. Carver and Verdirame (2001) studied refugee freedom of expression from a human rights perspective. Andersson (2013) outlined that political interests often drive governments' decisions to deliberately limit refugees' freedom of expression. The research is born out of adherence to Article 19 of the International Covenant on Civil and Political Rights (ICPR) which states that people in countries signatories to the Universal Declaration of Human Rights (UDHR) have the right to "seek, receive and impart information and ideas of all kinds..." and to have opinions "without interference" (UDHR, 1948). The limiting of individuals' right to speak out and of press freedom is a direct threat to this right.

In 2016, Turkey was home to over 2.7 million Syrian refugees. Despite being a signatory to the 1951 Refugee Convention, the country imposed a geographical restriction only granting refugee status to Europeans. Syrians are only permitted to reside in Turkey for a limited 
Volume 2, Issue 1: Special Issue (Forced) Migration and Media

period of time as "guests". These limitations restrict Syrians' access to legal employment, healthcare, education and housing. Most Syrian refugees in Turkey are waiting to be resettled to a third country, but constant changes in refugee law designed to prevent Syrians from reaching Europe, such as the "EU-Turkey deal", continue to make their legal situation even more precarious (Baban, Ilcan and Rygiel, 2016). Carver and Verdirame (2001), in their study on Kenya and Uganda, wrote that refugee press fulfils vital functions in their community such as voicing concerns and helping assess the potential to return home. However, Syrian refugee reporters in Turkey face killings, funding challenges, press freedom restrictions, as well as an uncertain legal status. Most of the publications studied in this article have a precarious legal status and authorities could shut them down any time. Thirty journalists were killed in Turkey in 2015 , several of whom were post-uprising Syrian journalists reporting on politics, human rights and corruption (CPJ, 2017).

With 65.6 million forcibly displaced people in the world in 2015 (UNHCR, 2017a), refugees' freedom of expression is of particular importance. Examining the challenges to the freedom of expression of Syrian refugee reporting provides insight into refugee freedom of expression as a whole. This article draws upon theories of the ideal role of a journalist in a society and on considerations how journalism has changed over time (Carpentier, 2005; Dahlgren, 2010 and Deuze, 2005). This article considers, beyond the threats to refugees' freedom of expression, the resilience mechanisms that refugee reporters deploy. This may inform other refugee journalists working in similar conditions, as well as donors who fund refugee reporting (IREX, 2016), of the specific barriers to refugee freedom of expression including their often uncertain legal status and the physical dangers refugee journalists can face.

\section{Literature review: Refugee journalists' freedom of expression- functions and} challenges

The limited research conducted on information precarity of refugees and refugee reporting points at the myriad of difficulties refugees face when trying to accurately cover the political situation in their countries of origin and discuss the problems their community are facing in their host country. The making of journalism has been a historical challenge for refugees. Leff (2015), for instance, points to the difficulties Jewish refugee reporters fleeing Nazi Germany 
Volume 2, Issue 1: Special Issue (Forced) Migration and Media

faced when they tried to exercise their profession in the United States. They encountered that journalism schools rebuffed requests to re-educate them with an often anti-semitic rationale.

While earlier it was mentioned that Article 19 of the ICPR foregrounds the right of refugees to speak out, international legislation can also be misused to stop refugees from undertaking journalistic activities that denounce or speak out about unpopular issues (Andersson, 2013). The Organization of African Unity (OAU)'s 1969 Convention Governing the Specific Aspects of Refugee Problems in Africa, for instance, specifically forbids refugees from engaging in "subversive activities" or "attacking" a member state of the OAU "through the press, or by radio" (OAU, 1969). In their research on refugee rights in Kenya and Uganda, Verdirame and Harrell-Bond (2005) showed how refugees engaging in journalism can be threatened with forced return, regardless of whether these countries are signatories to the 1951 Refugee Convention.

Major texts on journalistic scholarship such as the Handbook for Journalistic Studies do not recognise refugee press as a genre of its own (Wahl-Jorgensen and Hanitzsch, 2009), whereas studies have outlined the clear role of refugee press in society (Carver and Verdirame, 2001). Wall, Otis Campbell and Janbek (2017) found that Syrian refugees in Jordan sought information about the wellbeing of relatives left-behind, their crops and the conditions of the towns and cities where there had been attacks. The refugees in this study expressed, however, a lack of access to information regarding the material help available to them in the refugee camp. Refugee reporting can also be an important homemaking tool for those who may never be able to return home (Bonini, 2011).

In his article about Congolese refugees in a Rwandan camp, Kivikuru (2013) wrote that a lack of refugee voices in the international media has reinforced a soft colonial discourse. In a similar fashion Wall, Otis Campbell and Janbek (2017) found that international media portrayed the lives of refugees as having less value than those in the 'developed world'. The Syrian refugees in their study reported that journalists often took photos of them without their permission and printed distorted stories. At the same time, Palestinian reporters play an essential role in the production of international news about their society, but are often prevented from telling their own stories in the international media (Bishara, 2006). Despite having the skills to do the job, their contribution is usually as translators, producers and fixers. 
Volume 2, Issue 1: Special Issue (Forced) Migration and Media

Often, to keep their jobs at international news organisations, they avoid disclosing their views on the situation. These reporters also face security threats and Israeli-imposed mobility constraints. These challenges leave the stories of Palestinians' experiences in the hands of those with only particular political interests.

Journalistic objectivity has been used as a reason to prevent those affected by conflict to tell their own stories. However, literature about multiculturalism and multimedia reporting challenges this limiting view (Deuze, 2006) as these forms of reporting require collaboration across communities and often include a call for journalists to take a more active role in addressing issues such as inequality. Similarly, alternative and citizen journalism are born out of discontent with mainstream Western media portrayals. Often produced by people without formal journalistic qualifications and by the use of mobile devices and social media, these forms of reporting provide more background information and context in news reports. They give greater coverage to non-elite people and often see themselves as authors of social change (Atton, 2009, p. 265). Refugee journalism exists in a challenging media panorama, but it has the potential to help their community take greater ownership of the international conversation about their lives.

Refugee reporting shares similar characteristics with alternative and citizen journalism. Asthana (2017) looked at the use of inexpensive communication technologies by Palestinian youth to aid their struggle against Israeli occupation by performing activities such as a social media campaign to get innocent Palestinians released from prison. This form of reporting was political in nature and it enabled group formation among Palestinians. These productions strayed away from the view of refugee children as helpless victims, a view much in line with the neoliberal discourse of humanitarian narratives on children's rights. Asthana (2017) argues that such views perpetuate circles of violence and domination. Her research points at the potential of refugee journalism as a form of resistance against those narratives.

Syrian refugees in Jordan's largest refugee camp similarly took to social media to counteract false stories written about them, according to the study mentioned earlier, by Wall, Otis Campbell and Janbek (2017). They also found that Syrian refugees experienced a lack of access to communications technologies and faced surveillance by the Syrian regime. Since 2000, the Syrian regime has been blocking and censoring the internet. As the civil 
Volume 2, Issue 1: Special Issue (Forced) Migration and Media

uprising escalated in 2011, the government also began to prevent foreign journalists from entering Syria. Citizen journalism boomed during this information blackout and activists learned to work around government controls (Salama, 2012). For those telling these stories, they take the risk in the hope that the international community will hear their stories and respond.

A major challenge of refugee reporting is that it requires philanthropy to survive. Funding usually comes with conditions attached, as Scott, Bunce and Wright (2017) have shown in regard to the Integrated Regional Information Networks (IRIN). This online news agency was first founded by the United Nation's Office for the Coordination of Humanitarian Affairs (OCHA) to report on development issues. Journalists were told to avoid being critical of UN member states or of the humanitarian industry. Eventually, IRIN moved towards private sector funding, which also imposed agendas concerning particular business interests. Having several donors helped IRIN mitigate the power of conditional funding.

This section aimed to highlight the role of refugee press as an attempt by its communities to claim their right to freedom of expression and achieve social and political change. It provided a brief illustration of the challenges refugees face when trying to engage in journalism and an overview of the vital role information plays in the lives of those fleeing conflict. The doors of journalism are now opening to alternative voices such as those from refugees. Refugee freedom of expression can be better understood by viewing journalism as a form of freedom of speech and the potential for any individual to be a journalist. Telling stories about their community and expressing grievances is a human right that is systematically denied to refugees in many fronts.

\section{Theoretical framework: the ideal role of refugee press}

This section examines the ideal role of a journalist from a variety of perspectives, making an attempt to formulate an ideal role of refugee press. Comparing the ideal with the reality of refugee press will highlight the limitations that exist for achieving refugee press freedom. Journalism's role varies according to place, economic system and dominant political ideas. According to Carpentier (2005) the liberal and social responsibility models are the most dominant. In the liberal model, the media are seen as economically-independent, profitdriven enterprises. In the social responsibility model, the media remains a private entity, but 
Volume 2, Issue 1: Special Issue (Forced) Migration and Media

it carries public responsibility. In a study attempting to describe universal journalistic values Deuze (2005) found that being objective was important for many journalists. He defined objectivity as being neutral, fair and credible. He also came to the conclusion that many journalists valued autonomy and immediacy: journalists should be independent and able to gather the news quickly. Ethics, or having a sense of validity and legitimacy, was also highly valued for the reporters interviewed (p. 447).

One of the most significant journalistic values Deuze (2005) found is that of journalists as a fourth state or government's watchdog. In this context, the ideas of press freedom and autonomy become ever more important: of not being stopped from reporting on certain topics or expressing opinions. However, the concept of press freedom has not been without its critics. For example, Berg critiqued Western journalism as a powerful entity that has often sided with capitalistic power (2012). Litchtenberg (1987) also points out that journalism has traditionally been run by profit-driven, large corporations, which seeking the largest possible audience, may avoid coverage that is too demanding, controversial or disturbing. Traditionally, journalism professionals have claimed the right of freedom of speech on behalf of the public, something Hartley (2007) views as exclusive and undemocratic. The scholar cites Ian Hargreaves phrase that in a democracy everyone should be a journalist. Hartley (2007) stated that journalism is a human right, basing his opinion on Article 19 of the International Covenant of Civil and Political Rights (ICCR) (Hartley, 2007).

New or human interest journalism challenges the idea of objectivity (Carpentier, 2005) as defined earlier by Deuze (2005). Dahlgren (2010) wrote that journalists should make their production processes and knowledge gaps visible to the public. He devised criteria to define idealistic journalistic values and wrote that journalism should be accurate, adhere to facts and face consequences for malpractice, such as lies and disinformation. Although, most research on journalism has been done in the US, the profession has acquired an increasingly global character (Hartley, 2007; see also Dahlgren, 2010). Many journalism scholars like Dahlgren (2010) think it should represent a pluralism of voices.

While media ownership can influence coverage, ethically-done journalism is believed to play a positive role toward promoting democracy. Davis (2010) wrote that journalism embodies the "first draft of a community's history" and creates identity, social capital and a 
Volume 2, Issue 1: Special Issue (Forced) Migration and Media

sense of belonging, which she found made people more engaged with politics (Davis, 2010, p. 1). At present, journalism is transitioning from an era of big capital and professionalisation to an internet era where anyone can be a publisher of their own ideas. Refugee journalism is thus caught between trying to achieve large profits, which tends to be seen as legitimate and professional, and telling stories using available means such as mobile phones and social media.

\section{Methodology}

Empirical data for this research was gathered through semi-structured interviews. A preliminary interview was carried out with the editor of a refugee newspaper in a Kenyan refugee camp to inform the questionnaire for the interviews in Istanbul. Walliman (2016) mentions that there must be a common ground between the researcher and the people studied. As the researcher is herself a journalist, this commonality produced empathy and allowed the refugee journalists to explain the challenges they faced with greater depth. The researcher first focused on asking respondents about what subjects they were not able to cover as well as what logistical issues they faced. More direct questions were discussed later, such as security challenges experienced whilst doing their job and how they overcome these. The director of one international non-governmental organisation (INGO) shared background information and the criteria the INGO used for funding news outlets.

The researcher focused on news outlets run by Syrians in Turkey financed by Western NGOs. The respondents knew each other and most of them were part of the Syrian Network of Print Journalists (SNP), a collaborative network of Syrian media (OMRAN, 2016). Most are critical of the Syrian government. These respondents do not represent the entire panorama of the media in Syria, as there are, for instance, also state-run news outlets in Syria (SANA, 2017). Walliman (2016) points out that even with the largest amount of resources and time, no sample will be an exact representation of an entire population. Some of the information collected is confidential. This data was used for background research, but was not reproduced in the final paper to ensure the safety of participants. In total 13 people were interviewed for this article. They are not named to protect their safety. Respondents 1 to 7 are editors of postuprising Syrian media in Istanbul, Turkey on which the article is based. Respondent 8 is a Middle-East research consultant. Respondents 9 and 10 are a director at the Association de 
Volume 2, Issue 1: Special Issue (Forced) Migration and Media

Soutien aux Médias Libres (ASML) and a former program manager who administered funding for post-uprising Syrian media at Democracy Council. Respondents 11 to 13 are the editor of Kenyan refugee newspaper Kakuma News Reflector, a Syria-based reporter working for one of the Syrian editors interviewed and a school director at the Syrian Nour Association, an NGO based in Istanbul helping Syrian refugees. These last three interviewees provided background knowledge for this article.

The researcher drew upon newspaper clips and academic research to find information about the background of Syrian media, freedom of expression in Turkey and the origins of the Syrian civil conflict. Two reports on the development of Syria's post-uprising media were also gathered. A qualitative data analysis of the interviews was conducted using qualitative data analysis software. This resulted in the formation of themes regarding the challenges refugee reporters' experience, the ways to mitigate them and the role that these media outlets have in their community. Themes for challenges included logistical, funding, and security threats, among others. Translated summaries of three copies of the newspapers from the outlets analysed were used to corroborate some respondents' answers.

\section{Research outcomes: Challenges on Syrian refugee news outlets' freedom of expression}

The research found that limitations on the freedom of expression of Syrian refugee news outlets were all-encompassing, consisting not merely of self-censorship, but also of the outlets' inability to be economically viable, difficulties managing personnel in Syrian war zones and legal challenges as unrecognised refugees in Turkey. This section explains these challenges in-depth, along with the ways in which these media outlets have tried to mitigate them.

\subsection{Decreasing and conditional funding and NGO distrust}

Most respondents mentioned that funding was the biggest challenge to their press freedom. Most of them obtained funding from Western INGOs including the International Research \& Exchanges Board (IREX), the French Operator in Media Cooperation (CFI) and the Global Forum for Media Development (GFMD). Core donors such as the European Union usually finance media INGOs who in turn provide funding and training to Syrian media outlets. 
Volume 2, Issue 1: Special Issue (Forced) Migration and Media

Respondents mentioned that donors often impose editorial conditions on them. Some Syrian media outlets have closed down as a result of this. Respondent 10 said that the French government once requested to vet the news before publishing. An INGO director also said that there were "red lines" reporters could not cross: "No one could talk about sectarian violence or the dismantlement of Syria or the end of the Syrian nation" (Respondent 9).

Respondent 4 mentioned that funders were not allowed to interfere editorially with their outlet and Respondent 10 explained that many Syrian news organisations refuse funding that comes with editorial conditions. However, the existence of "red lines", as Respondent 9 points out, seems to imply a culture of self-censorship. This could impact the ability to report on for instance sectarian violence and was seen as a clear challenge to their ability to speak of certain topics. Some reporters mentioned that funding tended to go to Western-friendly outlets: "They believe in democracy, we believe in democracy. From this side they see that we deserve to be supported" (Respondent 6). Having the power to administer funding, INGOs can effectively influence coverage. Nonetheless, some examples in the coverage of the news outlets studied in this article critiqued Western interventions in the Middle East (Rushdi, 2016).

An average budget of one of the outlets in this study ranges from $\$ 5,000-\$ 30,000$ US per month on staff salaries, printing, distributing and equipment. One of the main issues discussed by respondents was that funding is usually provided for six months up to a year. Requirements to get funded include how large their audience is, as well as publications' quality and professionalism. Respondents mentioned that the pressure to secure funding often caused them to use specific communications channels that were not the most effective for them to reach their audience. There is "a great push for electronic", said Respondent 5. The respondent felt this compromised the role of refugee journalists in Syrian society since many people lack electricity and internet.

Many of the respondents do not think INGOs are investing in the true needs of refugee news outlets. They mentioned that INGOs often request attendance to journalistic trainings that they find to be redundant, considering many are already trained journalists. They also mentioned that the INGOs do not understand their society. Refugee news outlets are driven to take the aid to maintain good relationships with donors, and to make their outlets 
Volume 2, Issue 1: Special Issue (Forced) Migration and Media

economically viable. Several of the reporters interviewed sought alternative funding from international colleagues such as Al Arabiya, Politikan and Liberation, who help them fundraise. One Syrian reporter called this "clear" money, because it did not have conditions attached: "It's clear money, it's clear relationships. They understand us and we understand them" (Respondent 7).

Some outlets have tried with partial success to use advertising or charging for content. However, charging Syrians living in a war zone for information seems unethical to many respondents. Other outlets have tried to get donations from friends or Syrian businessmen, but these have come attached with requests for editorial control. Refugee news outlets are fighting for media independence, but the difficulty of making a profit from their work leaves them vulnerable to the editorial requests of their funders. "I think before we were fighting for independent media from the regime. Now we are fighting for independent media from everyone" (Respondent 7).

\subsection{Refugee reporting and legality}

The legal status of reporters

Many of the reporters interviewed had to flee their homes and homelands due to war. Turkey was considered to be the best available option in the region in terms of living conditions and their ability to run media outlets. However, their uncertain legal status presents great challenges to them. Many respondents showed an official ID-card explaining that in Turkey, they are classified as "guests", not as refugees. "I rent a home here and the owner he can get me out anytime at any moment, like any Syrian here in Turkey" (Respondent 7).

Their uncertain legal position limits their ability to work freely and make a living. Their ability to express grievances relating to their situation is also compromised as a result of this.

The legal status of news outlets

In 2014, Turkish authorities began to request that several of these news outlets obtain government licenses to operate. Most of the media outlets studied in this article were not licensed. Respondents said it is almost impossible for non-Turkish businesses to get a license. 
Volume 2, Issue 1: Special Issue (Forced) Migration and Media

If they would get one, Turkish authorities would be likely to censor and impose specific conditions on them:

"We might be required to have Turkish workers, be Turkish-including. Part of the publication has to be Turkish. It would become under the government control" (Respondent 3).

Some papers obtained a license to print and distribute, but not to operate as a news organisation. Respondent 5 explained that Turkish authorities once entered the office of an SNP paper and fined them for lacking a license. One editor managed to obtain an "awareness media" license. With this, the editor managed to avoid being known as a journalistic outlet, because this word could attract censorship. In Turkey, their publications are distributed illegally and distributors are often targeted. Respondents also mentioned that their publications are prohibited in refugee camps, where they resorted to smuggling them in. These difficulties in reaching their audiences limit their potential.

\subsection{Freedom of the press in Turkey}

Many respondents thought that it was easier to do journalism in Turkey than in Lebanon, a country that also hosts a large number of Syrian displaced people (UNHCR, 2017b). They mentioned that they stay out of the Turkish authorities' radar by writing in Arabic and by focusing on Syrian issues only. "We are cautious we don't address the Turkish issues. Those are restrictions we are putting ourselves on ourselves. Because Turkey is the only place we are left with to work" (Respondent 6). Even with these precautions publications and broadcasts are constantly monitored by the Turkish government.

The outlets are often interrogated about their coverage, particularly if it deals with Kurdish issues. Not reporting on issues of sectarian violence is a way they have found to avoid facing security threats in Turkey. These testimonies show that even after moving to Turkey in search of greater press independence, Syrian refugee media outlets have limited freedom of expression. In 2015, Turkey was called the "world's largest prison for journalists" by Reporters Without Borders (Tunc, 2013, p. 154). Journalists in Turkey are often accused without proof of having ties to Kurdish separatists and promoting terrorist propaganda. ${ }^{1}$ 
Volume 2, Issue 1: Special Issue (Forced) Migration and Media

\subsection{Security}

According to most respondents, their personnel in Syria experience the greatest security concerns. Their correspondents in Syria are constantly at risk of being arrested or killed. Their electronic devices are often tapped. After publishing a cover with the sentence "Je Suis Charlie Hebdo", Respondent 7 faced threats from Islamic armed groups in Syria. The respondent said this was commonplace. According to respondents, most of the outlets studied in this article are banned in regime strongholds. With all of these challenges, most are uncertain about the future:

"Actually it's one of the questions that we have asked ourselves. How can we send our message in an environment that refuses to talk about the truth sometimes? It's just like walking in a road full of mines. It's so dangerous" (Respondent 4).

In Syria, they receive threats from the regime, but also from Islamic militias. Reporters in this study said they had been targeted through the internet, which is one of their main ways to communicate with their correspondents in Syria:

"They sent us a message [saying] that we saw fear in your journalists and we scared your journalists. The war is not about the AK-47 or the F16. Our war is in real land and in electronic land. They sent us a threat in our website" (Respondent 4).

These reporters said they try to stay safe using Virtual Private Networks (VPN) and Tor browsers that allow them to bypass network surveillance and censorship. Their audiences in Syria also find innovative ways to access their content, such as solar power and engines that generate electricity to listen to radio. One radio station said it had built frequency towers in Syria.

According to several respondents, INGOs do not offer personal security measures for journalists in Syria, apart from teaching them internet security measures that they are already familiar with. Reporters try to stay safe by using nicknames, keeping their offices' locations secret and avoiding covering certain armed groups. One respondent said that agreements with certain armies and connections with friends and family were essential for operating in 
Volume 2, Issue 1: Special Issue (Forced) Migration and Media

Syria. Resorting to self-censorship to avoid being attacked or arrested limits these outlets' freedom of expression.

\subsection{Seeking solutions}

One of the most effective coping mechanisms the outlets in this study have developed has been to form alliances such as the Syrian Network of Print Journalists (SNP) (OMRAN, 2016). Most of the reporters interviewed belonged to this specific network. SNP members print and distribute using the same offices and networks. Gathering news is often done by transmitting information from Syria to Turkey over the telephone or through social media. Obtaining detailed information and fact-checking is often done by asking family members in Syria. Papers often use unnamed sources for security reasons.

Respondents mentioned that their network allows them to share training and expertise. Their long-term aim is to become mainstream media in Syria. To ensure they have high reporting standards across the network, they formed the Ethical Charter of Syrian Media Alliance (2015). They think the "ethics pact", as they refer to it, can help to ensure a place in the media landscape in post-conflict Syria where they hope to return to. While this ethics pact can serve to improve their legitimacy, it remains uncertain if it can guarantee these refugee journalists an environment of freedom of expression, or ensure their physical safety. Nonetheless, having an established ethical framework is promising for the future media of post-conflict Syria.

\section{Conclusions}

This article examined refugee freedom of expression by focusing closely on the challenges of seven Syrian post-uprising reporters in Turkey (Respondents 1 to 7). It drew upon theories about the role of freedom of expression in the lives of refugees, as well as research on the ideal role of journalism. It also studied the coping mechanisms of these reporters and whether they were able to fulfil the ideal role of refugee press. For a lot of these journalists, opposing the Syrian regime through the media is one of their ways to fight back. It was clear that reporters saw themselves as participants in the political situation in Syria and their role as that of promoting social, political and cultural change in Syria. 
Volume 2, Issue 1: Special Issue (Forced) Migration and Media

However, their ability to effect social change or to be government watchdogs in Syria is limited by challenges such as being banned, harassed or even killed by the regime in Syria (CPJ, 2015). Some of their coping mechanisms to stay safe in Syria include avoiding mentioning particular militias that play a role in the Syrian conflict. This limits their freedom of expression and their ability to fulfil their perceived role of bringing change to Syria. Added to these security challenges are the challenges that living as unrecognised refugees in Turkey bring about. Respondents experienced limits to their rights to live, work and run media organisations in Turkey. Carver and Verdirame (2001) mentioned that in an ideal state, refugee press would enable their community to express grievances about their situation as refugees. Considering that a focus on Syria appears to be a precondition to being able to operate in Turkey, the press freedom of Syrian refugee journalists in Turkey is far from the ideal.

Reporters considered funding the biggest challenge to their freedom of expression and spoke about having to focus on internet audiences in order to receive funding. Considering the precarious access to electricity and the internet, it can be stated that refugees, as well as those who have stayed in Syria, cannot fully access vital information on their rights and the situation in Syria. The ability of the outlets in this study to produce fair journalism including a pluralism of voices is also limited, because of funders' red lines on coverage, as well as the push for specific communications channels. Refugee reporters are not alone in this, because as was seen in the theoretical framework, mainstream, big-capital Western media organisations face similar challenges.

The lack of effective safety measures by INGOs to protect the personal safety of reporters is concerning, considering the large number of Syrian journalist casualties in Turkey over the last two years (CPJ Alerts, 2016). Despite all these obstacles, Syrian reporters in Turkey have found resourceful ways to operate, such as creating collaborative networks among themselves and with international press. Their ethics pact could provide them with legitimacy, and examples were found in which these reporters were able to critique Western interventions in Syria. Their resilience could also be observed as they obtained permits to operate in Turkey. Although Syrian refugee press in Turkey experience systematic challenges on many fronts, these methods could be of use to other refugee journalists in the world who are trying to create positive change. 


\section{Bibliography}

Andersson, E. (2013). Political rights for refugees in Uganda: A balance between stability in the state and respect for human rights. Master's thesis. Universitet UMEA. Available at: http://umu.divaportal.org/smash/get/diva2:713765/FULLTEXT01.pdf., Accessed on 05/28/16].

Asthana, S. (2017). Youth, self, other: A study of Ibdaa's digital media practices in the West Bank, Palestine. International Journal of Cultural Studies. Volume 20, Issue 1, pp. $100-117$.

Atton, C. (2009). Alternative and Citizen Journalism. In Wahl-Jorgensen and Hanitzsch, T. (eds) The Handbook of Journalism Studies (265-278). New York, New York: Routledge.

Baban, F., Ilcan, S. and Rygiel, K. (2016). Syrian refugees in Turkey: pathways to precarity, differential inclusion, and negotiated citizenship rights, Journal of Ethnic and Migration Studies. Volume 43, Issue 1, p. 41-57.

Berg, C. (2012). The Soviet origins of hate-speech laws. Institute of Public Affairs Review, Volume 64, Issue 2, pp. 14-19.

Bishara, A. (2006). Local hands, international news. Palestinian journalists and the international media, Ethnography. Volume 7, issue 1, pp. 19-46.

Bonini, T. (2011). The media as 'home-making' tools: life story of a Filipino migrant in Milan. Media, Culture \& Society. Volume 33, Issue 6, pp. 869-883.

Carpentier, N. (2005). Identity, contingency and rigidity. The (counter-)hegemonic constructions of the identity of the media professional. Journalism. Volume 6, Issue 2, pp. 199-219.

Carver, R. and Verdirame, G. (2001). Voices in Exile: African Refugees and Freedom of Expression, The Global Campaign for Free Expression. A report written for Article 19.

CPJ (2015). Journalists Killed: Turkey, Committee to Protect Journalists. Available at: https://cpj.org/killed/2015/naii-jerf.php, Accessed on: 03/18/16.

CPJ (2017). "25 Journalists Killed in Turkey/Motive Confirmed". Committee to Protect Journalists. Available at: https://cpi.org/killed/europe/turkey/, Accessed on 19/11/17.

CPJ Alerts (2016). "Syrian Journalist Killed in Turkey". CPJ Alerts Turkey. Available at: https://cpj.org/2016/04/syrian-journalist-killed-in-turkey.php, Accessed on 06/08/16.

Dahlgren, P. (2010). Charting the evolution of journalism: the horizon of democracy. Media Studies Volume 1, Issue (1-2), pp. 3-16.

Deuze, M. (2005). What is journalism? Professional identity and ideology of journalists reconsidered. Volume 6, Issue 4, pp. $442-464$.

Deuze, M. (2006). Ethnic media, community media and participatory culture. Journalism, Volume 7, Issue 3, pp. 262-280. 
Volume 2, Issue 1: Special Issue (Forced) Migration and Media

Ethical Charter for Syrian Media (2015). "Press Conference for the Launch of the Ethical Charter for Syrian Media". Available from: http://almethaq-sy.org/en/\#news, Accessed on 09/08/16.

Hartley, J. (2007). Journalism as a human right: the cultural approach to journalism. In Löffelholz, M. and Weaver, D. (Eds) Global Journalism Research Theories, Methods, Findings, Future (pp. 39-51), New York, New York: Peter Lang Publishers.

IREX (2016). "Our Supporters". IREX. Available at: https://www.irex.org/our-supporters. Accessed on 15/06/16.

Kivikuru, U. (2013). Upstairs downstairs: Communication contradictions around two African refugee camps, Journal of African Media Studies, Volume 5 Issue 1, pp. 35-51.

Leff, L (2015). Rebuffing Refugee Journalists. The Profession's Failure to Help Jews Persecuted by Nazi Germany, Journalism \& Communication Monographs. Volume 17, Issue, 3, pp.149-218.

Lichtenberg, J. (1987). Foundations and Limits of Freedom of the Press. Philosophy \& Public Affairs, Volume 16, Issue 4, pp. 329-355.

OAU (1969). OAU Convention Governing the Specific Aspects of Refugee Problems in Africa 1969. Available at: http://www.unhcr.org/uk/about-us/background/45dc1a682/oau-conventiongoverning-specific-aspects-refugee-problems-africa-adopted.html, Accessed on 15/07/16.

OMRAN (2016). OMRAN Center for Strategic Studies. Syrian Network of Print Media.

Rushdi, M. (2016). Is United Nations' Policy Innocent in Syria? Enab Baladi. Available at: http://english.enabbaladi.net/archives/2016/01/is-united-nations-policy-innocent-when-itcomes-to-syria/. Accessed on 10/04/16.

Salama, V. (2012). Covering Syria. The International Journal of Press/Politics. Volume 17, Issue 4, pp. 516-526.

Salazar-Ferro, M. (2014). Syrian Journalists Strive to Report, Despite Shifting Dangers. Committee to Protect Journalist. Available at: https://cpi.org/2014/02/attacks-on-the-press-syriaanalysis.php\#more, Accessed 08/09/16.

SANA (2017). Syrian Arab News Agency. Available at: http://sana.sy/en/?p=118174. Accessed on $15 / 11 / 17$

Shaheen, K. (2017). "Erdoğan to continue crackdown as Turkey marks failed coup". The Guardian. Available at: https://www.theguardian.com/world/2017/jul/15/erdogan-repeats-support-deathpenalty-on-anniversary-of-turkey-coup-attempt. Accessed on 15/11/17].

Tunc, A. (2013). Freedom of expression debates in Turkey: Acute problems and new hopes, International Journal of Media and Cultural Politics, Volume 9, Issue 2, pp.153-163.

UDHR (1948). Universal Declaration of Human Rights, 1948. Available at: http://www.ohchr.org/EN/UDHR/Documents/UDHR Translations/eng.pdf. Accessed on 20/08/16 
Volume 2, Issue 1: Special Issue (Forced) Migration and Media

UNHCR (2017a). "Figures at a glance. Statistical yearbook 2015". Available at http://www.unhcr.org/uk/figures-at-a-glance.html, Accessed on 26/10/17.

UNHCR (2017b). "Syria Regional Refugee Response". Inter-agency Information Sharing Portal. Available at: http://data.unhcr.org/syrianrefugees/country.php?id=122 Accessed on 17/11/17.

Verdirame, G., Harrell-Bond, B. (2005). Rights in Exile: Janus-Faced Humanitarianism. New York, New York: Berghahn books.

Wahl-Jorgensen, K., Hanitzsch, T. (Eds.) (2009). The Handbook of Journalism Studies. New York, New York: Routledge.

Walliman, N. (2016). Social Research Methods, London, England: SAGE.

Wall, M., Otis Campbell, M. and Janbek, D. (2017). Syrian refugees and information precarity. New Media \& Society. Volume 19, Issue 2, pp. $240-254$.

\section{Biography}

Maria Assaf is a Colombian-Canadian freelance reporter born in Bucaramanga, Colombia. Her journalistic career includes reporting for Latin American, Filipino and West Indian diaspora media as well as for mainstream newspapers in Canada such as the National Post's world section. She has a bachelor degree in journalism from Ryerson University and an MA in Development and Emergency Practice from Oxford Brookes University, where she researched Syrian refugee media freedom of expression in Istanbul, Turkey. In 2015, she travelled through Colombia's conflict areas as a research assistant and interpreter as part of a conflict transformation project on symbolic violence toward vulnerable communities in Valle del Cauca and Tolima. She currently works in strategic and change communications at Oxford Brookes University.

\footnotetext{
${ }^{1}$ After the coup attempt in July, 2016, the Turkish government began a large-scale crackdown on journalists, dissidents and human rights activists whom it alleges are perpetrators of the coup. This research was conducted a month before these events took place (Shaheen, 2017).
} 


\section{Contact author:}

Maria Assaf

massaf@brookes.ac.uk 